\title{
Analysis of factors affecting Ho Chi Minh city's office rental price using Hedonic model
}

\author{
Van Thuong Le ${ }^{1, *}$, Quynh Hoa Nguyen $^{2}$, and Van Toan Nguyen ${ }^{3}$ \\ ${ }^{1}$ University of Architecture Ho Chi Minh City, 196 Pasteur, Ho Chi Minh City, Vietnam \\ ${ }^{2}$ University of Economics Ho Chi Minh City \\ ${ }^{3}$ Tien Phong Commercial Joint Stock Bank
}

\begin{abstract}
Research on the application of Hedonic model in analyzing factors which affect office rental price in HCM city CBD area. The author uses primary data source comprised of 146 observations collected in district 1 and district 3 during the first 6 months of 2015. By using OLS method, together with three regression models commonly used in researches on the application of Hedonic model, the result shows significant impact of factors, such as building classification, management fee, road on which the building is situated, and district location on office rental price. The result of this research can be applied in the field of real estate management, investment consulting, office rental.
\end{abstract}

\section{Introduction}

Ho Chi Minh city, which situated in the center of Vietnam's Southern economic zone, is a major economic, culture and education center of the country. Ho Chi Minh city only accounts for $0.6 \%$ of Vietnam's total area and $8.34 \%$ of Vietnam's population but accounts for $23 \%$ of the country's total gross domestic products (GDP), and 1/3 of Vietnam's total industrial export value. The city also attracts most of Vietnam's direct foreign investments, government budget revenue and export. With such a strong and rapid growth, Ho Chi Minh city is considered one of the most potential real estate market and attracts most investments in the South-East Asia region, becoming the destination for many enterprises, investors, especially in the field of commerce - services. Because of this, office rental market here develops continuously and is one of the most dynamic sector of the city's real estate market. Therefore, researches on the office rental market, rental price, and factors affecting office rental price here are necessary.

\section{Theoretical Basis}

Hedonic valuation model (Hedonic Price Model - HPM) was formed from Andrew Court's researches (1939), developed and perfected by Lancaster (1966) and Rosen's (1974) researches. The term "hedonic" was derived from a Greek word "hedonikos", which means satisfaction. In economics, the term refers to usefulness, satisfaction via the consumption of

\footnotetext{
* Corresponding author: angela-1309.m@yandex.ru
} 
goods and services $[1,2]$. Hedonic valuation model was based on a theory that stating goods are a collection of many characteristics, and the price of goods connected with these characteristics. This means that the value of a commodity is based on its nature in the market in a particular period. These characteristics can be measured in size, speed, weight, etc. and will affect the value (selling or rental price) of that commodity.

Real estate market is one of the wide application of Hedonic model. In 1967, Ridker presented a relation between house price and the inside and outside characteristics, such as structure (area, number of rooms, type of construction); residential area characteristics (distance to workplace, school quality, crime rate); surrounding environment (air quality, water source, noise). From Ridker's research, during the last century, there's been a wide range of experimental researches on the relationship between selling price or rental price with its characteristics: Kain and Quigley (1970), Schafer (1979), Follain and Jimenez (1985), Gatzlaff and Smith (1993), Malpezzi (2002), Sergio (2002), Selim (2008), Monson (2009), Gabriel (2011), Shimizu (2014) and many other authors [3, 4].

According Malpezzi (1980), Hedonic valuation method uses a regression model of apartment's value or rental price based on the related characteristics of that apartment. Therein, each independent variable represents each separate characteristic and the coefficients in the model's result are the underlying price of these characteristics:

Where:

$$
R=f(S, N, L, C, T)
$$

$\begin{array}{ll}\mathrm{R} & \text { : rent or value } \\ \mathrm{S} & \text { : structural characteristics } \\ \mathrm{N} & \text { : neighborhood characteristics } \\ \mathrm{L} & \text { : location; } \\ \mathrm{C} & \text { : contract conditions, implicit and explicit } \\ \mathrm{t} & \text { : time trend }\end{array}$

In the office rental sector, there are also many researches on the application of Hedonic model, these researches are categorized into two groups:

- The first group focus on the impact of the office's inside and outside characteristics on the rental offering price. This group contains researches of Clap (1980), Hough and Kratz (1983), Frew and Jud (1988), Glascock, Jahanian and Sirmans (1990).

- The second group uses the actual rental price. In this group, there are important (noi bat) researches of Brennan, Cannaday and Colwell (1984), Wheaton and Torto (1994), Webb and Fisher (1996).

With the first four researches of Clapp, Hough and Cratz, Frew and Jud, Glascock, Jahanian and Sirmans, all office buildings are used as observation unit to explain rental variables. They calculated building's average rental price and the dependent variable, skipping the variation on rental prices in the same building. Clapp checked both supply demand of office buildings and his model is a good example on the impact of location on office rental price for later researches. Hough and Cratz proved that architecture quality also has a significant impact on rental price along with other important characteristics [5].

Frew and Jud introduced vacancy rate variable into Hedonic models and pointed out: leasers who are willing to accept higher average vacancy rate tend to have higher average rental price at any point of time [6].

Glascock, Jahanian and Sirmans estimated both models: one model for rental price level and other for rental price adjustment. Via price adjustment model, they can check for the changes in the rental price between observation periods. Therefore, they can explain changes in rental price with changes in market condition. The authors have improved Frew and Jud's model by adding vacancy rate variable in the rental price adjustment process. The result confirms that there is a negative relationship between vacancy rate and changes in rental price. 
The main characteristics of research models in the first group is that they are based on rental offering price. Although data on the actual rental price would be better to explain changes, previous models still use rental offering price. The reason for this is because there are certain difficulties in approaching the data on actual rental price on both lessor and lessee are not willing to disclose all their actual payments due to confidentiality in commerce. Even if they were to provide the actual data, such data might already exclude "non - commercial advantages". It is difficult to control all of such advantages on each transaction. Therefore, rental offering price is a preferable choice to overcome such problems [7,8].

Eda Ustaoğlu (2007) researched in Ankara and concluded that variables which are significant and strongly affect rental price are listed as follow: building's location, building's construction type, office building's services, size and office rental area, and dummy variable of a new renter. Maarten and Dirk (2009) research's result shows factors including location, size, age, and area of the building are determining factors for office rental price in Amsterdam. Saksith \& Kaiwan (2009) proved factors affecting rental price in Bangkok are the number of elevators in the building, whethere air conditioning systemisinstalled, and whether the building is situated inside or ouside of of Silom - Bangkok's central business district, building's age and railway accessibility [9-19].

In Vietnam, Nguyen Quoc Nghi and partners applied Hedonic model to point out factors affecting the price of rental apartments in Can Tho city. The result indicates significant factors are rental floor area, location, main street, living expenses of renter, form of rent and previous rental price, all of which has a regression coefficient similar with initial expectations.

\section{Method and research model}

\subsection{Research model}

This research uses three models commonly used in analysis on the application of Hedonic valuation model:

1. Simple linear model

$$
\mathrm{P}(\mathrm{Z})=\alpha 0+\sum \alpha i Z i+\varepsilon
$$

2. Semi-log model

$$
P(Z)=\alpha 0+\sum \alpha i \ln Z i+\varepsilon
$$

3. Linear $\log$ model

$$
\ln \mathrm{P}(\mathrm{Z})=\alpha 0+\sum \alpha \mathrm{iln} \mathrm{Zi}+\varepsilon
$$

Therein: dependent variable PRICE (USD/m2/month) is office rental price

$\mathrm{Zi}$ - independent variables, $\alpha \mathrm{i}$ - regression coefficients

Independent variable $\mathrm{Zi}$ - are factors affecting office rental price, and are proposed based on relevant researches and author's observations when researching office rental market in Ho Chi Minh city.

Grade A, Grade B, Grade C (Dummy variables): Office ranking variable in Ho Chi Minh city's central business district. In Vietnam, there is yet to be any general regulations on office building ranking. This research uses the standard ranking of Colliers International Vietnam to rank office buildings [9].

These are qualitative variables corresponding to 4 types of ranking, they are divided into 3 dummy variables: GradeA, GradeB, GradeC and are encoded as below: 
- GradeA: has a value of 1 if the building is ranked grade A. has a value of 0 if the building has other rank.

- GradeB: has a value of 1 if the building is ranked grade B. has a value of 0 if the building has other rank.

- GradeC: has a value of 1 if the building is ranked grade C. has a value of 0 if the building has other rank.

With three variables GradeA, GradeB, GradeC, the author expects to have a positive relationship with PRICE variable.

District (Dummy variable): District location, the research is for district 1 and district 3, this variable is expected to have a positive relationship with PRICE variable.

- Has a value of 1 if the building is located in district 1

- Has a value of 0 if the building is located in district 3

Nofloor (number of floors): Total number of office building's floor, excluding basement and ground floor, the Nofloor variable is expected to have a positive relationship with Price variable.

Fee (USD/m2/month): Monthly management fee, this variable is expected to have a positive relationship with the building's rental price.

Manager (Dummy variable): Management:

- Has a value of 1 if the building is managed by professional companies (CBRE, Colliers, Savills, Keppel Land).

- Has a value of 0 if the building is managed by its owners.

It is expected that the Manager variable will positively affect the PRICE variable.

Area $(\mathrm{m} 2)$ : Rental area on each floor of the building, the expected relationship is uncertain.

Street (Dummy variable): Main street:

- Has a value of 1 if the building is situated in the main street of the area

- Has a value of 0 if the building is not situated in the main street if the area

It is expected that the Street variable will have a positive relationship with PRICE.

Parking (Dummy variable): Parking basement:

- Has a value of 1 if the building has parking basement

- Has a value of 0 if the building does not have parking basement

It is expected that the Parking variable will be positive $(+)$.

Table 1. List of variables, description and expectation on relationship in the research model (Source: Author's survey).

\begin{tabular}{|c|l|c|c|}
\hline Variable & \multicolumn{1}{|c|}{ Description } & Variable Type & $\begin{array}{c}\text { Relationship } \\
\text { expectation }\end{array}$ \\
\hline PRICE & Office rental price & Quantitative & \\
\hline GradeA & Grade A office building & Dummy & + \\
\hline GradeB & Grade B office building & Dummy & + \\
\hline GradeC & Grade B office building & Dummy & + \\
\hline Nofloor & Number of floors & Quantitative & + \\
\hline Fee & Management fee & Quantitative & + \\
\hline District & District location & Dummy & + \\
\hline Manager & Management & Dummy & + \\
\hline Area & Area of each floor & Quantitative & $?$ \\
\hline Street & Location of the main road & Dummy & + \\
\hline Parking & Parking basement & Dummy & + \\
\hline
\end{tabular}

Simple linear model:

PRICE $=\alpha 0+\alpha 1$ Grade $\mathrm{A}+\alpha 2$ GradeB $+\alpha 3$ GradeC $+\alpha 4$ Nofloor $+\alpha 5$ Fee $+\alpha 6$ District + $\alpha 7$ Manager $+\alpha 8$ Area $+\alpha 9$ Street $+\alpha 10$ Parking $+\varepsilon$

Semi-log model (log - lin) 
$\ln (\mathrm{PRICE})=\alpha 0+\alpha 1$ GradeA $+\alpha 2$ GradeB $+\alpha 3$ GradeC $+\alpha 4$ Nofloor $+\alpha 5$ Fee $+\alpha 6$ District $+\alpha 7$ Manager $+\alpha 8$ Area $+\alpha 9$ Street $+\alpha 10$ Parking $+\varepsilon$

Linear log model

$\ln ($ PRICE $)=\alpha 0+\alpha 1$ GradeA $+\alpha 2$ GradeB $+\alpha 3$ GradeC $+\alpha 4 \ln ($ Nofloor $)+\alpha 5 \ln ($ Fee $)+$ $\alpha 6$ District $+\alpha 7$ Manager $+\alpha 8 \ln ($ Area $)+\alpha 9$ Street $+\alpha 10$ Parking $+\varepsilon$

The authors use Ordinary Least Squares method (OLS)with Eview 8 software to inspect and correct errors in the regression model.

\subsection{Data source}

Data source include 146 observations collected in district 1 and 3 during the first 6 months of 2015. In 146 office buildings observed in the center of Ho Chi Minh city, there are 107 buildings belong to district 1 and 39 buildings located in district 3 . In terms of building ranking, there are 10 buildings ranked grade A, 36 grade B, 25 grade C and 75 buildings ranked grade $\mathrm{D}$.

In terms of rental price, in 146 office buildings observed in the center of Ho Chi Minh city, the average rental price is $18.3 \mathrm{USD} / \mathrm{m} 2 /$ month, highest price belongs to Times Square building with $50 \mathrm{USD} / \mathrm{m} 2 / \mathrm{month}$, and lowest price belong to Loc Le building at 8.9 $\mathrm{USD} / \mathrm{m} 2 /$ month. The management fee varies from $2-8 \mathrm{USD} / \mathrm{m} 2 / \mathrm{month}$ depending on the building, but the average of the sample is around $4.2 \mathrm{USD} / \mathrm{m} 2 / \mathrm{month}$.

Table 2. Data description summary (Source: Author's survey).

\begin{tabular}{|l|c|c|c|c|}
\hline & PRICE & Nofloor & Fee & Area \\
\hline Mean & 18.31849 & 13.26712 & 4.157534 & 533.4863 \\
\hline Median & 16.00000 & 11.00000 & 4.000000 & 353.5000 \\
\hline Highest & 50.00000 & 68.00000 & 8.000000 & 4500.000 \\
\hline Lowest & 8.900000 & 4.000000 & 2.000000 & 82.00000 \\
\hline Standard Deviation & 7.747284 & 7.933596 & 1.410250 & 557.4168 \\
\hline Observations & 146 & 146 & 146 & 146 \\
\hline
\end{tabular}

\section{Regression result}

The regression result of three models are cited in table 3. In linear model, dependent variable is office rental price, in log-lin and log-log models, dependent variable is $\ln$ of office rental price [10].

Table 3. Regression result (Source: Author's survey and calculation).

\begin{tabular}{|c|c|c|c|}
\hline \multirow{2}{*}{ Variable } & Linear Model & Log - Lin Model & Log - Log Model \\
& & & \\
& 7.774888 & 2.248702 & 2.163237 \\
& $(3.808895)$ & $(21.48885)$ & $(12.60541)$ \\
\hline \multirow{2}{*}{ GRADEA } & $20.40497^{* * *}$ & $0.738041^{* * *}$ & $0.794888^{* * *}$ \\
& $(10.59305)$ & $(7.473805)$ & $(8.479323)$ \\
\hline \multirow{2}{*}{ GRADEB } & $5.344197^{* * *}$ & $0.284373^{* * *}$ & $0.292408^{* * *}$ \\
& $(4.561999)$ & $(4.735198)$ & $(4.726154)$ \\
\hline \multirow{2}{*}{ GRADEC } & $3.995631^{* * *}$ & $0.243254^{* * *}$ & $0.239172^{* * *}$ \\
& $(4.322278)$ & $(5.132919)$ & $(4.992601)$ \\
\hline
\end{tabular}




\begin{tabular}{|c|c|c|c|}
\hline FEE & $\begin{array}{c}1.330387^{* * *} * \\
(3.784477)\end{array}$ & $\begin{array}{c}0.077610^{* * *} \\
(4.306474)\end{array}$ & \\
\hline $\operatorname{Ln}(\mathrm{FEE})$ & & & $\begin{array}{c}0.294151 * * * \\
(4.334605)\end{array}$ \\
\hline STREET & $\begin{array}{l}1.217690^{*} \\
(1.711103)\end{array}$ & $\begin{array}{c}0.073391 * * \\
(2.011680)\end{array}$ & $\begin{array}{c}0.078547 * * \\
(2.194927)\end{array}$ \\
\hline DISTRICT & $\begin{array}{l}1.393722 * * \\
(2.018047)\end{array}$ & $\begin{array}{c}0.096918 * * \\
(2.737396) \\
\end{array}$ & $\begin{array}{c}0.102576 * * * \\
(2.928293)\end{array}$ \\
\hline NOFLOOR & $\begin{array}{c}0.038414 \\
(0.699712)\end{array}$ & $\begin{array}{c}0.002463 \\
(0.875196)\end{array}$ & \\
\hline Ln(NOFLOOR) & & & $\begin{array}{l}0.092567 * \\
(1.840900)\end{array}$ \\
\hline AREA & $\begin{array}{c}0.000146 \\
(0.214476)\end{array}$ & $\begin{array}{c}9.68 \mathrm{E}-07 \\
(0.027668)\end{array}$ & \\
\hline Ln(AREA) & & & $\begin{array}{c}-0.032709 \\
(-1.110947) \\
\end{array}$ \\
\hline MANAGER & $\begin{array}{c}-0.701961 \\
(-0.753815)\end{array}$ & $\begin{array}{c}-0.034632 \\
(-0.725445)\end{array}$ & $\begin{array}{c}-0.038458 \\
(-0.821159)\end{array}$ \\
\hline PARKING & $\begin{array}{c}-0.719992 \\
(-0.452409)\end{array}$ & $\begin{array}{c}-0.047145 \\
(-0.577856)\end{array}$ & $\begin{array}{c}-0.053899 \\
(-0.665239)\end{array}$ \\
\hline $\mathbf{R}^{2}$ & 0.820269 & 0.781209 & 0.787644 \\
\hline Adjusted R ${ }^{2}$ & 0.806955 & 0.771765 & 0.771914 \\
\hline $\begin{array}{l}\text { Prob (F- } \\
\text { statistic) }\end{array}$ & 0.000000 & 0.000000 & 0.000000 \\
\hline
\end{tabular}

Note: *: significant level of $10 \%, * *$ : significant level of $5 \%, * * *$ : significant level of $1 \%$.

The result of all three models shows AREA, MANAGER, PARKING variables does not have statistical significance, this indicates that there is no evidence on the relationship between office rental price and area on each floor, whether the building is managed by local or foreign company nor there is a parking basement in the building. The result also points out the relationship between office rental price with the building's ranking, management fee, main street and district location. GradeA, GradeB and GradeC variable's coefficients (Grade A office, Grade B office, Grade C office) is positive (+) as expected for the model. This implies that office rental price in grade $\mathrm{A}, \mathrm{B}$ and $\mathrm{C}$ is higher compare to the rental price in grade D buildings $[11,12]$.

The coefficient of FEE variable (Management fee) is also positive $(+)$ as previously expected. This indicates the management fee is positively related to office rental price. Management fee variable represents the quality of the office building, since good, modern buildings with high-end equipment and tend to have high management and rental fee. In contrast, smaller buildings with poorer interior bear lower management fee and thus, has lower rental price.

The coefficient of DISTRICT variable (district location) and STREET variable (main street) is positive $(+)$ as initially expected. This means office rental price in District 1 is higher than that of District 3 area, the rental price of buildings located in the main streets is also higher than rental price of buildings located on secondary roads [13].

Total floor number variable does not have statistical significance in linear and semi-log model, but in log-log model, when running regression with adjustment of standard deviation $\mathrm{HAC}$, the $\ln$ (Nolfoor) variable shows $10 \%$ of significance $[14,15]$.

\section{Conclusion}

The result of all three models shows significant impact of building's ranking, management fee, main street, and district location on office rental price. This result can be used to consult 
and advise individuals who are having a demand for renting an office and investors who wish to invest in building office for rent in the city's center area. The result can also be applied by the state for planning and managing the real estate market. Based on the regression model, we can recognize and evaluate the level of impact of factors mentioned in the model, this is crucial for planning, direct the office rental market in the future. For instance, an appropriate planning of main street, division of areas in city center, planning of residential or commercial area, placing office at the right location will maximize advantages of the real estate, achieving highest economic and social efficiency for the area.

\section{References}

1. T.P. Brennan, R.E. Cannaday, P.F. Colwell, Journal of the American Real Estate and Urban Economics Association 12-3, 243-260 (1984)

2. J.M. Clapp, Journal of Regional Science 20, 387-399 (1980)

3. A.T. Court, Hedonic Price Indexes with Examples, The Dynamics of Automobile Demand (General Motors, New York, 1939)

4. G. Kayode, Journal of Sustainable Development 4-1, 246 - 253 (2011)

5. J. Frew, G.D. Jud, Journal of Real Estate Research 3-1, 1-8 (1988)

6. J.L. Glascock, S. Jahanian, C.F. Sirmans, Journal of the American Real Estate and Urban Economics Association 18-1, 105-119 (1990)

7. D.E. Hough, C.G. Kratz, Journal of Urban Economics 14, 40-54 (1983)

8. J.F. Kain, J.M. Quigley, Journal of the American Statistical Association 65, 532-548 (1970)

9. K.J. Lancaster, Journal of Political Economym 74, 132-157 (1966)

10. S. Malpezzi, L. Ozanne, T. Thibodeau, Characteristic Prices of Housing in Fifty-Nine Metropolitan Areas, The Urban Institute in Washington DC, http://www.huduser.gov/portal/Publications/pdf/HUD-50814.pdf (1980)

11. S. Malpezzi, A Selective and Applied Review, Housing Economics and Public Policy (Blackwell Science Ltd, Oxford, 2002)

12. M. Monson, Cornell Real Estate Review 7, 62-73 (2009)

13. R.G. Ridker, J.A. Henning, The Reviewer of Economics and Statistics 49-2, 246-57 (1967)

14. S. Rosen, Journal of Political Economy 82-1, 35-55 (1974)

15. S. Chalermpong, K. Wattana, Journal of the Eastern Asia Society for Transportation Studies, 8 (2009)

16. R. Schafer, Journal of Urban Economics 6(2), 176-96 (1979)

17. S. Selim, DoğuşÜniversitesiDergisi 9(1), 65-76 (2008)

18. R.B. Webb, J.D. Fisher, Journal of Urban Economics 39, 1-19 (1996)

19. W.C. Wheaton, R.G. Torto, Journal of Urban Economics 35, 121-139 (1994) 